ORIGINAL RESEARCH PAPER

\title{
PHENOLICS COMPOSITION, ANTIOXIDANT AND PASTING PROPERTIES OF HIGH-QUALITY CASSAVA FLOUR SUBSTITUTED WITH Brachystegia eurycoma SEED FLOUR
}

\author{
EMMANUEL ANYACHUKWU IRONDI ${ }^{*}$, WASIU AWOYALE ${ }^{2,3}$, GANIYU OBOH $^{4}$, \\ ALINE AUGUSTI BOLIGON ${ }^{5}$

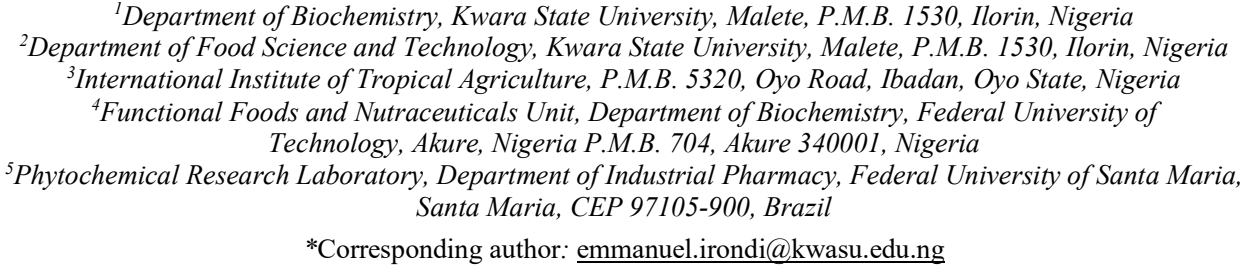

Received on 4 October 2018

Revised on 7 January 2019

\begin{abstract}
The increasing use of high-quality cassava flour (HQCF) for the baking of food products makes it imperative to improve its antioxidant and pasting attributes. Therefore, the phenolics composition, antioxidant and pasting properties of HQCF substituted with $10 \%$ and $20 \%$ Brachystegia eurycoma seed flour (BSF) were evaluated in this study. The HPLC-DAD profile of the phenolics revealed that chlorogenic acid, caffeic acid, rutin and quercetin levels in the blends increased significantly $(p<0.05)$ as the proportion of BSF increased. DPPH* $(2,2-$ Diphenyl2-picrylhydrazyl radical) and ABTS $*^{+}$[2,2-azinobis (3-ethyl-benzothiazoline-6sulfonic acid) radical cation] scavenging activities, and $\mathrm{Fe}^{2+}$ chelating capacity of the blends increased significantly $(p<0.05)$ with increasing proportion of BSF. As the proportion of BSF in the blends increased, the amylose content reduced; this fact was accompanied with an increase of the trough, final and set-back viscosities, and a decrease of the peak and breakdown viscosities of the blends. Therefore, the substitution with BSF enhanced the antioxidant and pasting properties of HQCF.
\end{abstract}

Keywords: antioxidant activity, Brachystegia eurycoma, cassava flour, phenolics, pasting characteristics

\section{Introduction}

Cassava (Manihot esculenta Cranz), belonging to the Euphorbiaceae family, is a dicotyledonous perennial plant grown in the tropical regions of the world, where it serves as the third most important energy source and one of the major subsistence crops, next to rice and maize (Uarrota and Maraschin, 2015). Cassava roots are

https//doi.org/10.35219/foodtechnology.2019.1.01 
processed into a variety of traditional products such as gari, lafun, abacha, fufu and starch for human consumption (Kormawa et al., 2003). In addition to these traditional products, fresh cassava roots are also processed into high-quality cassava flour (HQCF). HQCF is an unfermented cassava flour produced from freshly harvested cassava roots within a day of harvest. It has several applications including the making of biscuits and confectioneries, starch, dextrin, seasonings, adhesives and hydrolysates for pharmaceuticals (Ene, 1992). Several studies showed that HQCF can be blended in various proportions with wheat flour to form composite flours that are used for the baking of different food products (Eleazu et al., 2014; Khalil et al., 2000).

The use of a composite flour consisting of wheat and other staple crops for baking bread and other food products is gaining more popularity due to some economic, health and social reasons (Eduardo et al., 2013). Economically, wheat importation was noted to pose a major burden on the importing countries due to its high cost, causing a decline in foreign exchange and over-dependence on foreign foods (Ohimain, 2014). However, the flours used as substitutes of wheat flour, including HQCF, are associated with considerable technological difficulties, the reason being that their proteins lack gluten and cannot form the necessary gluten network characteristic to wheat flour for holding the gas produced during the fermentation (Gallagher et al., 2003). This limitation usually leads to baked products with inferior qualities (Defloor et al., 1993). One of the possible ways of overcoming this limitation is the addition of hydrocolloids, which were shown to have the potential to serve as gluten substitutes in the formulation of gluten-free breads (Guarda et al., 2004). The hydrocolloids were also shown to enhance the moisture retention and the viscoelastic characteristics of the dough for baked foods (Eduardo et al., 2013). However, using synthetic hydrocolloids and other additives to improve the quality of baked products may increase their cost of production (Ohimain, 2014). In addition to hydrocolloids, the amylose and amylopectin contents of flours and starches influence their pasting properties (Jane et al., 1999). Gelatinization and pasting, in turn, influence the texture, digestibility and end use of starchy foods; and are therefore, two of the most important properties taken into consideration in the food industry for the quality and aesthetic value of food products (Maziya-Dixon et al., 2005).

Similarly, synthetic antioxidants such as butylated hydroxyltoluene are added to flours to improve the antioxidant properties of the baked products. However, due to the potential harmful effects of such synthetic antioxidants, studies demonstrated the effectiveness of substituting baking flours with rich sources of natural dietary antioxidants, with a view to improve the antioxidant properties of the composite flour (Ahmed, 2014; Irondi et al., 2017), and consequently, those of the baked products. In recent years, natural dietary antioxidants attracted researches attention due to their contribution in offering protection against various diseases (Omar et al., 2012) such as diabetes, obesity, hypertension and cancer. Among the natural dietary antioxidants, phenolic compounds are very prominent, having a wide distribution in the plant kingdom (Duan et al., 2006). In addition to their 
antioxidant properties, phenolic compounds are known to impact the nutritional and commercial properties of food products through their influence on the sensory properties such as flavor (Perez-Lopez et al., 2007) and pasting properties (Zhu et al., 2008).

Brachystegia eurycoma harms, a member of the Caesalpinoideae family, is an underutilized legume that thrives mostly in the West African tropical rain forest. It has both food and ethnomedicinal uses (Irondi et al., 2015a). In West Africa, the edible seeds flour is used as a natural thickening agent in soups (Uhegbu et al., 2009), for bakery products and for starch production (Ikegwu et al., 2010). These food uses of B. eurycoma seeds flour are attributable to its high content of hydrocolloids (Nwakaudu et al., 2017). Furthermore, a recent study demonstrated that the seeds flour is rich in phenolic compounds, and exhibits antidiabetic effect in type 2 diabetic rats (Irondi et al., 2015a). In a related study, methanol extract of $B$. eurycoma seeds flour was reported to inhibit some enzymes relevant to type 2 diabetes, including $\alpha$-amylase, $\alpha$-glucosidase and aldose reductase (Irondi et al., 2015b).

The increasing use of HQCF in baking food products calls for research efforts to improve its antioxidant and pasting properties, and consequently, improve its health benefits and food applications. In view of the richness of $B$. eurycoma seeds flour (BSF) in phenolic compounds and hydrocolloids as reported by previous studies, it may be suitable as a low-cost natural dietary source to improve the antioxidant and pasting properties of HQCF. Therefore, this study evaluated the phenolics composition, antioxidant and pasting properties of HQCF substituted with BSF.

\section{Materials and methods}

\section{Materials}

Freshly harvested white-flesh cassava roots were obtained from a local cassava farmer; while dried B. eurycoma seeds were bought from a local market in Akinyele, Ibadan, Nigeria. Afterwards, the samples were authenticated at the Botany Department, University of Ibadan, Nigeria. All the chemicals used for the various analyses were of analytical grades.

\section{Preparation of samples}

\section{High quality cassava flour (HQCF) preparation}

The freshly harvested white-flesh cassava roots $(8 \mathrm{~kg})$ were peeled, washed, grated, dewatered, and sieved. Thereafter, the sieved mash was oven-dried at $40{ }^{\circ} \mathrm{C}$ and milled into flour of $0.5 \mathrm{~mm}$ particle size to obtain the HQCF.

\section{B. eurycoma seeds flour (BSF) preparation}

A seeds sample of B. eurycoma $(2 \mathrm{~kg})$ was sorted, shelled manually and ground into $0.5 \mathrm{~mm}$ particle size to obtain the BSF. 


\section{HQCF-BSF blends preparation}

HQCF was substituted with BSF at $0 \%, 10 \%$ and $20 \%$ levels to produce $100 \% \mathrm{HQCF}, 90 \% \mathrm{HQCF}-10 \% \mathrm{BSF}$ and $80 \% \mathrm{HQCF}-20 \% \mathrm{BSF}$ blends, respectively, used for the study. The flours were packed in separate airtight plastic containers and kept in refrigerator for further analysis.

\section{Flours extract preparation}

A portion of $2 \mathrm{~g}$ of each flour sample was extracted by soaking in $20 \mathrm{~mL}$ of absolute $(100 \%)$ methanol overnight. Thereafter, the mixture was centrifuged at $4000 \mathrm{rpm}$ for $5 \mathrm{~min}$, and the supernatant was collected by filtering through Whatman (No. 2) filter paper. The methanol in the filtrate was removed using a rotatory evaporator at $45^{\circ} \mathrm{C}$, after which the dried extract was diluted to $6 \mathrm{~mL}$ with methanol (Engida et al., 2013).

\section{Analysis of phenolic compounds using HPLC-DAD}

The phenolic compounds in the flours were quantified using a reverse-phase HPLC-DAD (Shimadzu, Kyoto, Japan) connected to a diode array detector (SPDM20A) and a personal computer with a LC solution software (1.22 SP1). Forty (40) $\mu \mathrm{L}$ of each flour extract was injected at $20 \mathrm{mg} / \mathrm{mL}$ and a flow rate of 0.6 $\mathrm{mL} / \mathrm{min}$, and separation of the phenolic compounds was carried out using reversed phase Phenomenex $\mathrm{C}_{18}$ column $(4.6 \mathrm{~mm} \times 250 \mathrm{~mm})$ packed with particles of $5 \mu \mathrm{m}$ diameter. The mobile phase consisted of solvent A, comprising water, methanol and acetic acid in the ratio of 95:3:2 (v/v/v), and solvent B, comprising acetonitrile and formic acid in the ratio of $98: 2(\mathrm{v} / \mathrm{v})$. Prior to injection, the extracts and mobile phase were filtered through a $0.45 \mu \mathrm{m}$ (Millipore) membrane filter, and degassed in an ultrasonic bath. The gradient program used was as previously described by Boligon et al. (2015). Stock solutions $(0.030-0.500 \mathrm{mg} / \mathrm{mL})$ of the phenolic compounds standards were prepared using the mobile phase. The chromatography peaks were integrated using the external standard method, at $254 \mathrm{~nm}$ for gallic acid; $327 \mathrm{~nm}$ for chlorogenic and caffeic acids; and $366 \mathrm{~nm}$ for quercetin and rutin. The sample peaks identification and quantification of their corresponding phenolic compounds were done by matching their retention times and DAD spectral (200 to $600 \mathrm{~nm})$ to those of the reference standards. Triplicate determinations of each sample were performed at ambient temperature.

\section{DPPH $^{*}$ scavenging assay}

$\mathrm{DPPH}^{*}$ scavenging ability of the extracts was determined according to the method described by Cervato et al. (2000), using ascorbic acid as positive control. In brief, a reaction mixture consisting of $1.0 \mathrm{~mL}$ of different concentrations $(0.15,0.30,0.45$ and $0.60 \mathrm{mg} / \mathrm{mL}$ ) of the extract and $3.0 \mathrm{~mL}$ of $60 \mu \mathrm{M} \mathrm{DPPH}{ }^{*}$ solution was incubated at room temperature for $30 \mathrm{~min}$. Thereafter, the absorbance was measured at $517 \mathrm{~nm}$ in a UV-Vis spectrophotometer, and the $\mathrm{DPPH}^{*}$ scavenging ability percentage of the extracts was calculated.

\section{ABTS $^{*+}$ scavenging assay}

ABTS $^{*+}$ scavenging ability of the extracts was determined according to the method described by Re et al. (1999). ABTS*+ reagent was prepared by thoroughly mixing 
equal volume of $\mathrm{ABTS}^{*+}(7 \mathrm{mM})$ and $\mathrm{K}_{2} \mathrm{~S}_{2} \mathrm{O}_{8}(2.45 \mathrm{mM})$ aqueous solutions, and incubating it in the dark at room temperature for $16 \mathrm{~h}$. Afterwards, the absorbance of the reagent was adjusted to $0.7 \pm 0.02$ at $734 \mathrm{~nm}$ using $95 \%$ ethanol. A reaction mixture consisting of $2.0 \mathrm{~mL}$ of the $\mathrm{ABTS}^{*+}$ reagent and $0.2 \mathrm{~mL}$ of the flour extracts was incubated at room temperature for $15 \mathrm{~min}$, following which the absorbance was measured at $734 \mathrm{~nm}$ in a UV-Vis spectrophotometer. ABTS ${ }^{*+}$ scavenging ability of the extracts was subsequently calculated from Trolox standard curve, and expressed in micromole Trolox equivalent antioxidant capacity per gram $(\mu \mathrm{mol} \mathrm{TEAC} / \mathrm{g})$.

\section{Iron (II) $\left(\mathrm{Fe}^{2+}\right)$ chelating assay}

The ability of the extracts to chelate $\mathrm{Fe}^{2+}$ was determined using the method reported by Puntel et al. (2005). Shortly, to a reaction mixture containing $168 \mu \mathrm{L}$ $0.1 \mathrm{M}$ Tris- $\mathrm{HCl}(\mathrm{pH} 7.4), 218 \mu \mathrm{L}$ normal saline and different concentrations of the extracts $(0.30,0.60,0.90$ and $1.20 \mathrm{mg} / \mathrm{mL}), 150 \mu \mathrm{L}$ of freshly prepared $\mathrm{FeSO}_{4}(500$ $\mu \mathrm{M})$ was added. The mixture was then incubated for $5 \mathrm{~min}$ at room temperature, after which $13 \mu \mathrm{L}$ of $0.25 \% 1,10$-phenanthroline was added. Subsequently, the absorbance was measured at $510 \mathrm{~nm}$ in a UV-Vis spectrophotometer, and the $\mathrm{Fe}^{2+}$ chelating ability of the extracts was calculated. The $\mathrm{Fe}^{2+}$ chelating ability of the extract was expressed as the concentration of extract that chelated $50 \%$ of $\mathrm{Fe}^{2+}$ $\left(\mathrm{SC}_{50}\right)$ in $\mathrm{mg} / \mathrm{mL}$.

\section{Determination of amylose and amylopectin contents}

Amylose content of the flours was determined by the method described by Juliano et al. (1981). Briefly, $100 \mathrm{mg}$ of the flour sample was mixed with $1 \mathrm{~mL}$ of $95 \%$ ethanol and $9.2 \mathrm{~mL}$ of $1 \mathrm{~N} \mathrm{NaOH}$, and the mixture was heated in a water bath at $100^{\circ} \mathrm{C}$ for $10 \mathrm{~min}$ to gelatinize the starch. After cooling to room temperature, 0.5 $\mathrm{mL}$ of diluted extract was mixed with $0.1 \mathrm{~mL}$ of $1 \mathrm{~N}$ acetic acid solution, $0.2 \mathrm{~mL}$ of iodine solution $\left(0.2 \% \mathrm{I}_{2}\right.$ in $\left.2 \% \mathrm{KI}\right)$ and $9.2 \mathrm{~mL}$ of distilled water. The reaction mixture was incubated at room temperature for $20 \mathrm{~min}$, after which the absorbance was measured at $620 \mathrm{~nm}$ in a UV-Vis spectrophotometer. Subsequently, amylose content of the samples was calculated using amylose as a standard.

Amylopectin content of the flour samples was calculated by difference, using the formula reported by Juan et al. (2006):

$$
\text { Amylopectin (\%) = } 100-\text { amylose }(\%)
$$

\section{Determination of pasting properties}

The pasting properties of the flours were determined using a Rapid Visco Analyzer (RVA) (RVA-4, Perten Scientific, Springfield, IL) as reported by Deffenbaugh and Walker (1989). The RVA was equipped with a personal computer (PC) containing the Thermocline software. The pasting characteristics of a suspension obtained from $3 \mathrm{~g}$ flour in $25 \mathrm{~mL}$ of distilled water, including peak viscosity, trough, breakdown, final viscosity, set back, peak time, and pasting temperature, were read on the PC with the help of the Thermocline software. The measurements were performed in triplicate, and the results were expressed in Rapid Visco Analyzer units (RVU). 


\section{Statistical analysis of data}

Results of triplicate determinations were presented as mean \pm standard deviation (SD), and subjected to one-way analysis of variance (ANOVA) and least significant difference (LSD) tests at $95 \%$ confidence level using the $17^{\text {th }}$ version of the SPSS statistical software.

\section{Results and discussion}

HPLC-DAD profile of the phenolic compounds in the flours revealed the presence of gallic acid (peak 1), chlorogenic acid (peak 2), caffeic acid (peak 3), rutin (peak 4) and quercetin (peak 5) (Figure 1). The levels of the various phenolic compounds identified are presented in Table 1. Generally, the levels of all the phenolic compounds, except gallic acid, were low in the 100\% HQCF. Interestingly, the levels of chlorogenic acid, caffeic acid, rutin and quercetin increased significantly $(p<0.05)$ in the blends (90\% HQCF-10\% BSF and $80 \%$ HQCF- $20 \%$ BSF) as the proportion of BSF increased. Overall, quercetin had the highest percentage increase $(580 \%$ ), from $0.15 \pm 0.02 \mathrm{mg} / \mathrm{g}$ in $100 \% \mathrm{HQCF}$ to $1.02 \pm 0.01 \mathrm{mg} / \mathrm{g}$ in $80 \%$ HQCF-20\% BSF; whereas gallic acid had the lowest percentage increase (3.72\%), from $2.15 \pm 0.01 \mathrm{mg} / \mathrm{g}$ in $100 \% \mathrm{HQCF}$ to $2.23 \pm 0.01 \mathrm{mg} / \mathrm{g}$ in $80 \% \mathrm{HQCF}-20 \%$ BSF.

Table 1. Phenolic composition of HQCF and the obtained HQCF-BSF blends

\begin{tabular}{lllllc}
\hline Compounds & $\begin{array}{l}100 \% \mathrm{HQCF} \\
(\mathrm{mg} / \mathrm{g})\end{array}$ & $\begin{array}{l}\text { 90\%HQCF- } \\
10 \% \mathrm{BSF} \\
(\mathrm{mg} / \mathrm{g})\end{array}$ & $\begin{array}{l}80 \% \mathrm{HQCF}- \\
20 \% \mathrm{BSF} \\
(\mathrm{mg} / \mathrm{g})\end{array}$ & $\begin{array}{l}\text { Retention } \\
\text { time } \\
(\mathrm{min})\end{array}$ & $\begin{array}{l}\text { Increase } \\
(\%)\end{array}$ \\
\hline Gallic acid & $2.15 \pm 0.01^{\mathrm{a}}$ & $1.08 \pm 0.03^{\mathrm{b}}$ & $2.23 \pm 0.01^{\mathrm{a}}$ & 10.45 & 3.72 \\
Chlorogenic acid & $0.39 \pm 0.02^{\mathrm{c}}$ & $1.57 \pm 0.01^{\mathrm{b}}$ & $2.27 \pm 0.04^{\mathrm{a}}$ & 20.11 & 482.05 \\
Caffeic acid & $0.96 \pm 0.01^{\mathrm{c}}$ & $2.03 \pm 0.01^{\mathrm{b}}$ & $2.54 \pm 0.02^{\mathrm{a}}$ & 26.37 & 164.58 \\
Rutin & $0.49 \pm 0.02^{\mathrm{c}}$ & $0.97 \pm 0.03^{\mathrm{b}}$ & $1.58 \pm 0.01^{\mathrm{a}}$ & 39.08 & 222.45 \\
Quercetin & $0.15 \pm 0.02^{\mathrm{b}}$ & $0.97 \pm 0.02^{\mathrm{a}}$ & $1.02 \pm 0.01^{\mathrm{a}}$ & 44.61 & 580.00 \\
\hline
\end{tabular}

Values are expressed as the mean \pm standard deviations (SD) of triplicate analyses.

The average values with different superscript letters along the same row vary significantly at $p<0.05$.

Although, to the best of our knowledge, there is no existing report on the phenolic profile of HQCF to compare our results, studies on the phenolic profile of other root and tuber crops including white skin sweet potato (Salawu et al., 2014) and bitter yam (Salawu et al., 2017) indicated the presence of the same phenolic compounds. The increase in the levels of chlorogenic acid, caffeic acid, rutin and quercetin observed with the increasing proportion of BSF in the blends may be directly attributed to the contribution from the BSF. A previous study showed that B. eurycoma seed flour (BSF) contained abundant levels of these phenolics (Irondi et al., 2015a). The same study reported that caffeic and chlorogenic acids, which are the predominant phenolics in the blends in this present study, were also the most abundant phenolic acids in BSF (Irondi et al., 2015a). This increase of the phenolics suggests that the substitution of HQCF with BSF may enhance the 
typical health benefits of these phenolic compounds, such as antiobesity, antidiabetic, antihypertensive and antioxidant activities (Irondi et al., 2016; Oboh et al., 2012).

a)
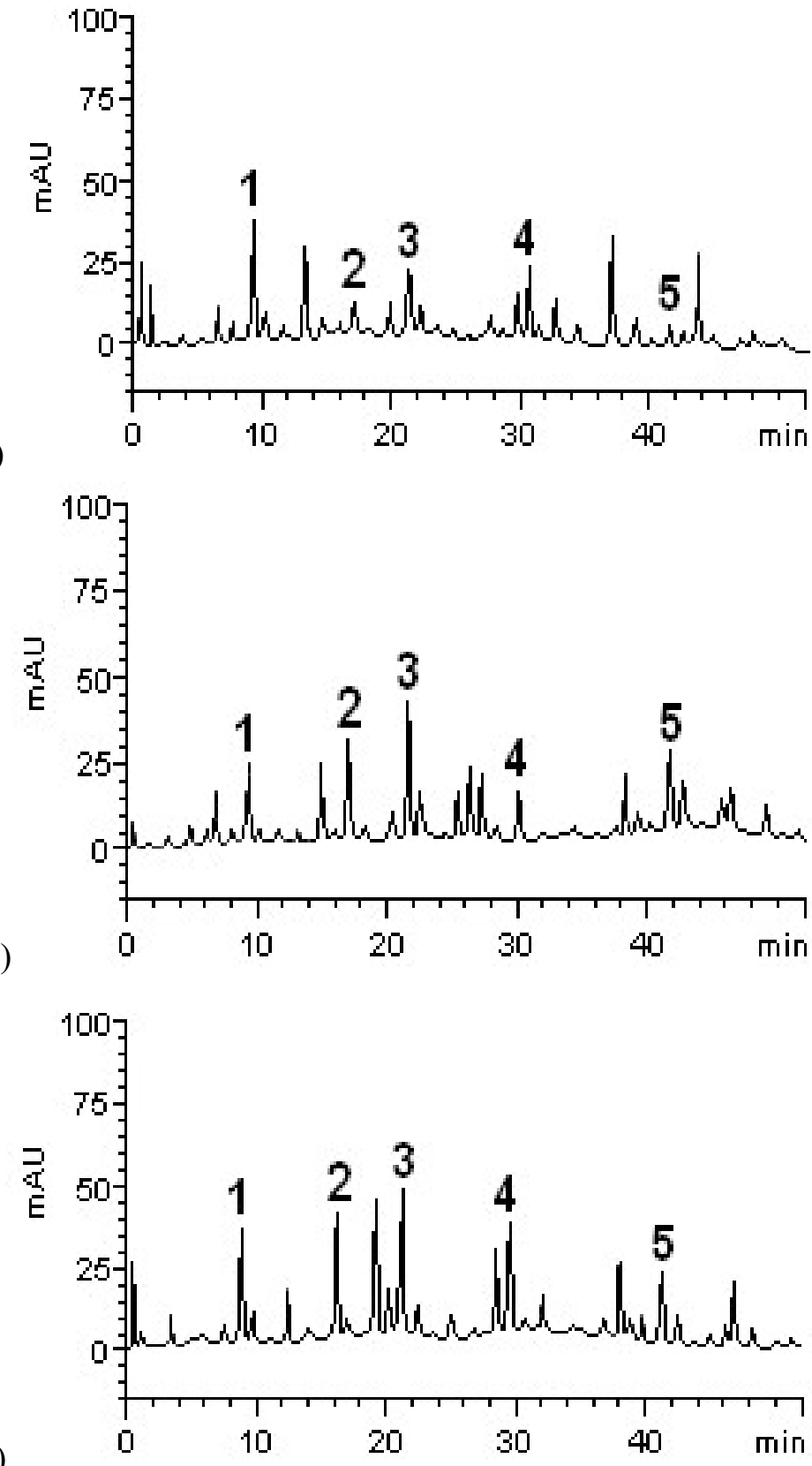

Figure 1. HPLC-DAD chromatograms of 100\%HQCF (a), 90\%HQCF-10\%BSF (b) and $80 \%$ HQCF-20\%BSF (c). Peak 1- gallic acid; peak 2- chlorogenic acid; peak -: caffeic acid; peak 4- rutin; peak 5- quercetin 
The antioxidant activity of the flours is presented in Table 2 . In line with the phenolics profile, the $\mathrm{DPPH}^{*}$ and $\mathrm{ABTS}^{*+}$ scavenging, and $\mathrm{Fe}^{2+}$ chelating abilities of the $100 \%$ HQCF were low, improving as the proportion of BSF in the blends increased. The $\mathrm{DPPH}^{*} \mathrm{SC}_{50}$ of the flours decreased significantly $(p<0.05)$ from $0.48 \pm 0.06 \mathrm{mg} / \mathrm{mL}$ in $100 \%$ HQCF to $0.41 \pm 0.04 \mathrm{mg} / \mathrm{mL}$ and $0.32 \pm 0.03 \mathrm{mg} / \mathrm{mL}$ in the $90 \% \mathrm{HQCF}-10 \% \mathrm{BSF}$ and $80 \% \mathrm{HQCF}-20 \% \mathrm{BSF}$, respectively. This trend inversely indicates that $80 \% \mathrm{HQCF}-20 \%$ BSF had the strongest $\mathrm{DPPH}^{*}$ scavenging ability, followed by $90 \%$ HQCF- $10 \%$ BSF and 100\% HQCF. Ascorbic acid, a reference antioxidant, had a much lower $\mathrm{DPPH}^{*} \mathrm{SC}_{50}(0.03 \pm 0.01 \mathrm{mg} / \mathrm{mL})$ than the flours, indicating its stronger $\mathrm{DPPH}^{*}$ scavenging ability. Similarly, the $\mathrm{Fe}^{2+}$ chelation $\mathrm{SC}_{50}$ of the flours decreased significantly $(p<0.05)$ from $0.92 \pm 0.11$ $\mathrm{mg} / \mathrm{mL}$ in $100 \%$ HQCF to $0.73 \pm 0.10 \mathrm{mg} / \mathrm{mL}$ and $0.54 \pm 0.08 \mathrm{mg} / \mathrm{mL}$ in the $90 \%$ HQCF-10\% BSF and 80\% HQCF-20\% BSF, respectively; indicating an inverse increasing order of $\mathrm{Fe}^{2+}$ chelation. The $\mathrm{ABTS}^{*+}$ scavenging ability of the blends increased significantly $(p<0.05)$ from $120.55 \pm 1.71 \mu \mathrm{mol}$ TEAC/g in $100 \% \mathrm{HQCF}$ to $146.19 \pm 2.13 \mu \mathrm{mol}$ TEAC/g in $90 \% \mathrm{HQCF}-10 \% \mathrm{BSF}$ and $181.86 \pm 2.92 \mu \mathrm{mol}$ $\mathrm{TEAC} / \mathrm{g}$ in $80 \% \mathrm{HQCF}-20 \% \mathrm{BSF}$, as the proportion of BSF increased. However, BSF $(100 \%)$ showed a much stronger antioxidant activity than the blends.

Table 2. $\mathrm{DPPH}^{*}$, $\mathrm{ABTS}^{*+}$ scavenging and $\mathrm{Fe}^{2+}$ chelation abilities of HQCF, BSF and the obtained flour blends

\begin{tabular}{lllllc}
\hline $\begin{array}{l}\text { Antioxidant } \\
\text { activity }\end{array}$ & $100 \% \mathrm{HQCF}$ & $100 \% \mathrm{BSF}$ & $\begin{array}{l}90 \% \mathrm{HQCF}- \\
10 \% \mathrm{BSF}\end{array}$ & $\begin{array}{l}80 \% \mathrm{HQCF}- \\
20 \% \mathrm{BSF}\end{array}$ & $\begin{array}{l}\text { Ascorbic } \\
\text { acid }\end{array}$ \\
\hline $\begin{array}{l}\text { DPPH* } \\
(\mathrm{mg} / \mathrm{mL})\end{array}$ & $0.48 \pm 0.06^{\mathrm{a}}$ & $0.05 \pm 0.01^{\mathrm{d}}$ & $0.41 \pm 0.04^{\mathrm{b}}$ & $0.32 \pm 0.03^{\mathrm{c}}$ & $0.03 \pm 0.01^{\mathrm{e}}$ \\
$\begin{array}{l}\mathrm{ABTS} *^{*+} \\
\text { scavenging } \\
\text { ability ( } \mu \mathrm{mol}\end{array}$ & $120.55 \pm 1.7^{\mathrm{d}}$ & $984.42 \pm 5.63^{\mathrm{a}}$ & $146.19 \pm 2.13^{\mathrm{c}}$ & $181.86 \pm 2.92^{\mathrm{b}}$ & - \\
$\begin{array}{l}\mathrm{TEAC} / \mathrm{g}) \\
\mathrm{Fe}^{2+} \text { chelation }\end{array}$ & $0.92 \pm 0.11^{\mathrm{a}}$ & $0.21 \pm 0.01^{\mathrm{d}}$ & $0.73 \pm 0.10^{\mathrm{b}}$ & $0.54 \pm 0.08^{\mathrm{c}}$ & - \\
$\mathrm{SC}_{50}(\mathrm{mg} / \mathrm{mL})$ & & & & & - \\
\hline
\end{tabular}

Values are expressed as the mean \pm standard deviations (SD) of triplicate analyses.

Average values with different superscript letters along the same row vary significantly at $p<0.05$.

$\mathrm{SC}_{50}$ : concentration of flour extract that scavenged $50 \%$ of $\mathrm{DPPH}^{*}$.

The increased trend of the antioxidant activity of the flour blends observed in this study is similar to that of wheat flour blended with flour of some other staples, as reported by some previous studies (Ahmed, 2014; Irondi et al., 2017). This increase may be attributed to the increase of the levels of the various phenolic compounds due to BSF substitution. Phenolic compounds are prominent for their antioxidant activity, conferred by their redox properties, which enable them to act as singlet oxygen quenchers, hydrogen donors and reducing agents (Chang et al., 2001). The increase of the free radicals scavenging ability of the flour blends suggests that the substitution of HQCF with BSF may boost the ability of baked food products to protect the body from the harmful effects of free radicals, such as oxidative damage to cellular biomolecules (proteins, nucleic acids, carbohydrates 
and lipids) (Takemoto et al., 2009) and oxidative stress-related chronic diseases (Ward et al., 2008). Similarly, the increase of the $\mathrm{Fe}^{2+}$ chelation ability suggests that the blends, by forming insoluble complexes with $\mathrm{Fe}^{2+}$, could help mitigate the $\mathrm{Fe}^{2+}$-mediated generation of hydroxyl radical $\left(\mathrm{OH}^{-}\right)$from hydrogen peroxide $\left(\mathrm{H}_{2} \mathrm{O}_{2}\right)$ (Oboh et al., 2008), and $\mathrm{Fe}^{2+}$-catalyzed lipid oxidation (Hsu et al., 2003), thereby protecting against oxidative stress.

The amylose and amylopectin contents of the flours are presented in Table 3. The levels of amylose in the blends significantly $(p<0.05)$ decreased with the increasing proportion of BSF, from $28.45 \pm 0.36 \%$ in the $100 \% \mathrm{HQCF}$ to $22.54 \pm 0.42 \%$ in the $90 \% \mathrm{HQCF}-10 \% \mathrm{BSF}$ and $18.63 \pm 0.35 \%$ in the $80 \% \mathrm{HQCF}-20 \% \mathrm{BSF}$. Inversely, their amylopectin contents increased significantly $(p<0.05)$ with the increasing proportion of BSF, from $71.55 \pm 0.36 \%$ in the $100 \% \mathrm{HQCF}$ to $77.46 \pm 0.42 \%$ in the $90 \% \mathrm{HQCF}-10 \% \mathrm{BSF}$ and $81.37 \pm 0.35 \%$ in the $80 \% \mathrm{HQCF}-20 \% \mathrm{BSF}$. The amylose/amylopectin ratios of the flours decreased with the increasing proportion of BSF in the blends. However, BSF $(100 \%)$ had the lowest amylose content $(0.82$ $\pm 0.03 \%$ ), the highest amylopectin content $(99.18 \pm 0.94 \%)$ and the least amylose/amylopectin ratio $(0.01)$.

Table 3. Amylose and amylopectin contents of HQCF, BSF and the obtained flour blends

\begin{tabular}{lccc}
\hline \multicolumn{1}{c}{ Sample } & Amylose (\%) & Amylopectin (\%) & Amylose: Amylopectin \\
\hline $100 \% \mathrm{HQCF}$ & $28.45 \pm 0.36^{\mathrm{a}}$ & $71.55 \pm 0.36^{\mathrm{d}}$ & 0.40 \\
$100 \% \mathrm{BSF}$ & $0.82 \pm 0.03^{\mathrm{d}}$ & $99.18 \pm 0.94^{\mathrm{a}}$ & 0.01 \\
$90 \% \mathrm{HQCF}-10 \% \mathrm{BSF}$ & $22.54 \pm 0.42^{\mathrm{b}}$ & $77.46 \pm 0.42^{\mathrm{c}}$ & 0.29 \\
$80 \% \mathrm{HQCF}-20 \% \mathrm{BSF}$ & $18.63 \pm 0.35^{\mathrm{c}}$ & $81.37 \pm 0.35^{\mathrm{b}}$ & 0.23 \\
\hline
\end{tabular}

Values are expressed as the mean \pm standard deviations (SD) of triplicate analyses.

Average values with different superscript letters along the same column vary significantly at $p<0.05$.

Generally, amylopectin content of the flours were higher than the amylose content, in line with the reports of previous studies that indicated that amylopectin is the predominant component of most starches (Yotsawimonwat et al., 2008). The amylose and amylopectin content of flours were reported to influence their functional properties, and consequently, their food and industrial applications (Irondi et al., 2017). In addition, amylose and amylopectin content of flours/starches impacts their glycemic index; with a lower amylose and a higher amylopectin content leading to a higher glycemic index (Shanita et al., 2011), due to their relative ease of digestion by a-amylase in human duodenum (Birt et al., $2013)$. Thus, the lower amylose contents of blends (90\%HQCF-10\%BSF and $80 \% \mathrm{HQCF}-20 \% \mathrm{BSF}$ ) relative to that of $100 \% \mathrm{HQCF}$, is an indication that they will have higher digestibility than the 100\%HQCF (Riley et al., 2006), and consequently, higher glycemic index.

The pasting properties of the flours are presented in Table 4 . The trough, final and set-back viscosities of the flours increased significantly $(p<0.05)$ as the proportion of BSF in the blends increased. Conversely, the peak and breakdown viscosities of 
the blends decreased significantly $(p<0.05)$, with increasing proportion of BSF. However, the peak time and pasting temperatures were comparable $(p>0.05)$. The trough viscosity increased from $179.17 \pm 0.32 \mathrm{RVU}$ in $100 \% \mathrm{HQCF}$, to $207.58 \pm$ 0.58 and $241.42 \pm 0.46 \mathrm{RVU}$ in $90 \% \mathrm{HQCF}-10 \% \mathrm{BSF}$ and $80 \% \mathrm{HQCF}-10 \% \mathrm{BSF}$, respectively. Similarly, the final viscosity increased from $279.75 \pm 0.51 \mathrm{RVU}$ in $100 \% \mathrm{HQCF}$, to $329.50 \pm 0.77$ and $390.08 \pm 0.89 \mathrm{RVU}$ in $90 \% \mathrm{HQCF}-10 \% \mathrm{BSF}$ and $80 \% \mathrm{HQCF}-10 \% \mathrm{BSF}$, respectively; while the set-back viscosity increased from $100.58 \pm 0.29 \mathrm{RVU}$ in $100 \% \mathrm{HQCF}$, to $121.92 \pm 0.23$ and $148.67 \pm 0.66 \mathrm{RVU}$ in $90 \% \mathrm{HQCF}-10 \% \mathrm{BSF}$ and $80 \% \mathrm{HQCF}-10 \% \mathrm{BSF}$, respectively. Trough viscosity, also known as holding strength or hot paste viscosity, is the least viscosity value during the constant temperature phase of RVA test, which measures the capacity of the paste to withstand breakdown during cooling. Thus, the higher trough viscosities of the blends suggest that their paste can withstand breakdown better than that of $100 \% \mathrm{HQCF}$ during cooling, as higher trough viscosity reflects lower breakdown of flour starches.

Final viscosity, which is the change in the viscosity after holding cooked starch at $50{ }^{\circ} \mathrm{C}$, indicates the stability of the cooked starch and the paste resistance to shear force during stirring. Among the pasting properties, it is the most commonly used index to determine the quality of a particular flour/starch (Maziya-Dixon et al., 2005). The higher final viscosity of the blends is an indication that they may be of better quality than the $100 \% \mathrm{HQCF}$, and consequently, will be more appropriate than the $100 \% \mathrm{HQCF}$ for obtaining food products, which require high viscosity starch (Moorthy, 2002). As Miles et al. (1985) reported, the increase in final viscosity could be a result of the aggregation of the amylose molecules in the starch of the flours. Set-back viscosity is the viscosity of cooked paste after cooling to 50 ${ }^{\circ} \mathrm{C}$, during which there is retrogradation or re-association of the amylose and amylopectin molecules in the starch. It indicates the stability of the paste as well as its retrogradation tendency (Liang and King, 2003). Thus, the higher set-back viscosities of the blends, relative to that of the $100 \% \mathrm{HQCF}$, is an indication of a higher tendency of their starch molecules to more readily disperse in hot paste and re-associate during cooling (Chinma et al., 2010). The blends may therefore be more suitable for products that require high viscosity and paste stability at low temperature (Oduro et al., 2000) than the 100\%HQCF.

The peak viscosity of the flours decreased from $561.33 \pm 0.94 \mathrm{RVU}$ in $100 \% \mathrm{HQCF}$ to $512.83 \pm 0.82$ and $492.67 \pm 0.91 \mathrm{RVU}$ in $90 \% \mathrm{HQCF}-10 \% \mathrm{BSF}$ and $80 \% \mathrm{HQCF}-$ $10 \% \mathrm{BSF}$, respectively. Peak viscosity indicates the tendency of starch granules to swell freely, before their physical breakdown. Similarly, the breakdown viscosity decreased from $382.17 \pm 0.92 \mathrm{RVU}$ in $100 \% \mathrm{HQCF}$ to $305.25 \pm 0.66$ and $251.25 \pm$ 0.72 RVU in $90 \% \mathrm{HQCF}-10 \% \mathrm{BSF}$ and $80 \% \mathrm{HQCF}-10 \% \mathrm{BSF}$, respectively. Breakdown viscosity reflects the tendency of swollen starch granules disintegration (Kaur and Singh, 2005), which is dependent on the material nature, temperature, mixing degree and the shear force applied to the mixture. The peak time of flour paste reflects their cooking time. Since the peak time of the 100\%HQCF and the blends were comparable, they may have similar cooking time. 
The pasting temperature is the minimum temperature needed to cook a starchy sample, and its attainment is necessary for the swelling, gelatinization and pasting of starch during processing (Offia-Olua, 2014). Thus, with a comparable pasting temperature, the energy cost of cooking the $100 \% \mathrm{HQCF}$ and the blends may be similar. Taken together, the improved pasting properties of the blends suggest that they may be better than 100\%HQCF for products development.

\section{Conclusions}

The substitution of high-quality cassava flour (HQCF) with Brachystegia eurycoma seed flour (BSF) led to an increase in the levels of chlorogenic acid, caffeic acid, rutin and quercetin in the blends as the proportion of BSF increased. The antioxidant activity of the blends also increased with the increasing proportion of BSF. Amylose content of the blends reduced, and this was accompanied by an increase in the trough, final and set-back viscosities, and a decrease in the peak and breakdown viscosities of the blends, as the proportion of the BSF in the blends increased. Therefore, the substitution with BSF enhanced the antioxidant and pasting properties of HQCF; suggesting that BSF may be a low-cost natural source to improve the health benefits, as well as the quality of HQCF for food applications. Further studies to understand the impact of BSF substitution on the physicochemical and sensory properties of products made from the blends are recommended.

\section{Conflict of interest statement}

There is no conflict of interest pertaining to this study. 


\section{References}

Ahmed, A.R. 2014. Influence of chemical properties of wheat-lupine flour blends on cake quality. American Journal of Food Science and Technology, 2, 67-75.

Birt, D.F., Boylston, T., Hendrich, S., Jane, J.L., Hollis, J., Li, L., McClelland, J., Moore, S., Phillips, G.J., Rowling, M., Schalinske, K., Scott, M.P., Whitley, E.M. 2013. Resistant starch: promise for improving human health. Advances in nutrition, 4, 587601.

Boligon, A.A., Piana, M., Kubiça, T.F., Mario, D.N., Dalmolin, T.V., Bonez, P.C., Weiblen, R., Lovato, L., Alves, S.H., Campos, M.M.A., Athayde, M.L. 2015. HPLC analysis and antimicrobial, antimycobacterial and antiviral activities of Tabernaemontana catharinensis A. DC. Journal of Applied Biomedicine, 13, 7-18.

Cervato, G., Carabelli, M., Gervasio, S., Cittera, A., Cazzola, R., Cestaro, B. 2000. Antioxidant properties of oregano (Origanum vulgare) leaf extracts. Journal of Food Biochemistry, 24, 453-65.

Chang, S.T., Wu, J.H., Wang, S.Y., Kang, P.L., Yang, N.S., and Shyur, L.F. 2001. Antioxidant Activity of Extracts from Acacia confuse Bark and Heartwood. Journal of Agriculture and Food Chemistry, 49, 3420-3424.

Chinma, C.E., Abu, J.O., Ojo, J.A. 2010. Chemical, Functional and Pasting Properties of Starches from Brown and Yellow Tigernuts (Cyperus esculentus). Nigerian Food Journal, 28, 1-13.

Deffenbaugh, L.B., and Walker, C.E. 1989. Comparison of starch pasting properties in the brabender Viscoamylograph and the Rapid Visco-Analyzer. Cereal Chemistry, 66, 499.

Defloor, I., Nys, M., Delcour, J.A. 1993. Wheat starch, cassava starch, and cassava flour impairment of the breadmaking potential of wheat flour. Cereal Chemistry, 70, 526530.

Duan, X-J., Zhang, W-W., Li, X-M., Wang, B-G. 2006. Evaluation of antioxidant property of extract and fractions obtained from a red alga, Polysiphonia urceolata. Food Chemistry, 95, 37-43.

Eduardo, M., Svanberg, U., Oliveira, J., Ahrné, L. 2013. Effect of Cassava Flour Characteristics on Properties of Cassava-Wheat-Maize Composite Bread Types. International Journal of Food Science, doi:10.1155/2013/305407.

Eleazu, C., Eleazu, K., Aniedu, C., Amajor, J., Ikpeama, A., Ebenzer, I. 2014. Effect of partial replacement of wheat flour with high quality cassava flour on the chemical composition, antioxidant activity, sensory quality, and microbial quality of bread. Preventive Nutrition and Food Science, 19, 115-123.

Ene, L.S.O. 1992. Prospects for processing and utilization of root and tuber crops. In National Root Crops Promotion of Root Crop-Based Industries, 7-11.

Engida, A.M., Kasim, N.S., Tsigie, Y.A., Ismadji, S., Huynh, L.H., Ju, Y. 2013. Extraction, identification and quantitative HPLC analysis of flavonoids from sarang semut (Myrmecodia pendan). Industrial Crops and Products, 41, 392-396.

Gallagher, E., Gormley, T.R., Arendt, E.K. 2003. Crust and crumb characteristics of gluten free breads. Journal of Food Engineering, 56, 153-161.

Guarda, A., Rosell, C.M., Benedito, C., Galotto, M.J. 2004. Different hydrocolloids as bread improvers and antistaling agents. Food Hydrocolloids, 18, 241-247. 
Hsu, C.L., Chen, W., Weng, Y.M., Tseng, C.Y. 2003. Chemical composition, physical properties, and antioxidant activities of yam flours as affected by different drying methods. Food Chemistry, 83, 85-92.

Ikegwu, O.J., Okechukwu, P.E., Ekumankana, E.O. 2010. Physico-chemical and pasting characteristics of flour and starch from Achi Brachystegia eurycoma seed. Journal of Food Technology, 8(2), 58-66.

Irondi, A.E., Oboh, G., Akindahunsi, A.A., Boligon, A.A., Athayde, M.L. 2015a. Phenolics composition and antidiabetic property of Brachystegia eurycoma seed flour in high-fat diet, low-dose streptozotocin-induced type 2 diabetes in rats. Asian Pacific Journal of Tropical Disease, 5(Suppl 1), S159-S165.

Irondi, A.E., Oboh, G., Akindahunsi, A.A. 2015b. Methanol extracts of Brachystegia eurycoma and Detarium microcarpum seeds flours inhibit some key enzymes linked to the pathology and complications of type 2 diabetes in vitro. Food Science and Human Wellness, 4, 162-168.

Irondi, A.E., Agboola, S.O., Oboh, G., Boligon, A.A. 2016. Inhibitory effect of leaves extracts of Ocimum basilicum and Ocimum gratissimum on two key enzymes involved in obesity and hypertension in vitro. Journal of Intercultural Ethnopharmacology, 5, 396-402.

Irondi, A.E., Awoyale, W., Oboh G., Boligon, A.A. 2017. Effect of mango kernel flour addition on the phenolics profile, antioxidant activity and pasting properties of wheat flour. Journal of Food Measurement and Characterization, 11(4), 2202-2210.

Jane, J., Chen, Y.Y., Lee, L.F., McPherson, A.E., Wong, K.S., Radosavljevic, M., Kasemsuwan, T. 1999. Effects of amylopectin branch chain length and amylose content on the gelatinization and pasting properties of starch. Cereal Chemistry, 76, 629-637.

Juan, G., Luis, A., David, B. 2006. Isolation and molecular characterization of Makal (Xanthosoma yucatanensis) starch. Starch, 58, 300-307.

Juliano, B.O., Perez, C.M., Blakeney, B. 1981. International Cooperative testing on the amylose content of milled rice. Starch, 33, 157-162.

Kaur, M., and Singh, N. 2005. Studies on functional thermal and pasting properties of flours from different chickpea (Cicer arietinum L.) cultivars. Food Chemistry, 91, 403-411.

Khalil, A.H., Mansour, E.H., Dawoud, F.M. 2000. Influence of malt on rheological and baking properties of wheat-cassava composite flours. LWT-Food Science and Technology, 33, 159-164.

Kormawa, P., and Akoroda, M.O. 2003. Cassava Supply Chain Arrangement for Industrial Utilization in Nigeria. Ibadan.

Liang, X., and King, J.M. 2003. Pasting and Crystalline Property Differences of Commercial and Isolated Rice Starch with Added Amino Acids. Journal of Food Science, 68, 832838.

Maziya-Dixon, B., Adebowale, A.A., Onabanjo, O.O., Dixon, A.G.O. 2005. Effect of variety and drying methods on physico-chemical properties of high quality cassava flour from yellow cassava roots. African Crop Science Conference Proceedings, 7, 635-641. 
Miles, M.J., Morris, V.J., Orford, P.D., and Ring, G.S. 1985. The roles of amylose and amylopectin in the gelation and retrogradation of starch. Carbohydrate Research, $\mathbf{1 3 5}$, 271-281.

Moorthy, S. 2002. Tuber crop starches. Technical Bulletin No. 18 CTCRI, Trivandrum.

Nwakaudu, A.A., Nwakaudu, M.S., Owuamanam, C.I., Alagbaoso, S.O., Njoku, N.E., Agunwah, I.M., Ofoedu, C., Ojukwu, M., Ofoegbu, J.C., Anikwenze, R.O. 2017. Extraction and evaluation of hydrocolloids from "Achi" (Brachystegia eurycoma) and its application on a water melon fruit juice. European Journal of Food Science and Technology, 5, 22-28.

Oboh, G., Raddatz, H., Henle, T. 2008. Antioxidant properties of polar and non-polar extracts of some tropical green leafy vegetables. Journal of the Science of Food and Agriculture, 88, 2486-2492.

Oboh, G., Ademiluyi, A.O., Akinyemi, A.J., Henle, T., Saliu, J.A., Schwarzenbolz, U. 2012. Inhibitory effect of polyphenol-rich extracts of Jute leaf (Corchorus olitorius) on key enzyme linked to type- 2 diabetes ( $\alpha$-amylase and $\alpha$-glucosidase) and hypertension (angiotensin I converting) in vitro. Journal of Functional Foods, 4, 450-458.

Oduro, I., Ellis, W.O., Dziedzoave, N.T., Nimakoyeboah, K. 2000. Quality of gari from selected processing zones in Ghana. Food Control, 11, 297-303.

Offia-Olua, B.I. 2014. Chemical, Functional and Pasting Properties of Wheat (Triticum spp)-Walnut (Juglans regia) Flour. Food and Nutrition Sciences, 5, 1591-1604.

Ohimain, E.I. 2014. The prospects and challenges of cassava inclusion in wheat bread policy in Nigeria. International Journal of Science, Technology and Society, 2, 6-17.

Omar, N.F., Hassan, S.A., Yusoff, U.K., Abdullah, N.A.P., Wahab, P.E.M., Sinniah, U.R. 2012. Phenolics, Flavonoids, Antioxidant Activity and Cyanogenic Glycosides of Organic and Mineral-base Fertilized Cassava Tubers. Molecules, 17, 2378-2387.

Perez-Lopez, A.J., del Amor, F.M., Serrano-Martinez, A., Fortea, M.I., Nunez-Delicado, E. 2007. Influence of agricultural practices on the quality of sweet pepper fruits as affected by maturity stage. Journal of the Science of Food Agriculture, 87, 2075-2080.

Puntel, R.L., Nogueira, C.W., Rocha, J.B.T. 2005. Krebs cycle intermediates modulate thiobarbituric reactive species (TBARS) production in Rat Brain in vitro. Neurochemical Research, 30, 225-235.

Re, R., Pellegrini, N., Proteggente, A., Pannala, A., Yang, M., Rice-Evans, C. 1999. Antioxidant activity applying an improved ABTS radical cation decolorization assay. Free Radical Biology and Medicine, 26, 1231-1237.

Riley, C.K., Wheatley, A.O., Asemota, H.N. 2006. Isolation and characterization of starches from eight Dioscorea alata cultivars grown in Jamaica. African Journal of Biotechnology, 5, 1528-1536.

Salawu, S.O., Boligon, A.A., and Athayde, M.L. 2014. Evaluation of antioxidant potential and nutritional values of white skinned sweet potato-unripe plantain composite flour blends. International Journal of Applied Research in Natural Products, 7, 11-20.

Salawu, S.O., Ajiboye, P.B., Akindahunsi, A.A., Boligon, A.A. 2017. Antioxidant and Anticholinesterase Potential of Two Nigerian Bitter Yams Using a Simulated Gastrointestinal Digestion Model and Conventional Extraction. Preventive Nutrition and Food Science, 22, 107-117. 
Shanita, S.N., Hasnah, H., Khoo, C.W. 2011. Amylose and Amylopectin in Selected Malaysian Foods and its Relationship to Glycemic Index. Sains Malaysiana, 40, 865870 .

Takemoto, K., Tanaka, M., Iwata, H., Nishihara, R., Ishihara, K., Wang, D.H., Ogino, K., Taniuchi, K., Masuoka, N. 2009. Low catalase activity in blood is associated with the diabetes caused by alloxan. Clinica Chimica Acta, 407, 43-46.

Uarrota, V.G., and Maraschin, M. 2015. Metabolomic, enzymatic, and histochemical analyzes of cassava roots during postharvest physiological deterioration. BMC Research Notes, 8, 648 .

Uhegbu, F.O., Onwuchekwa, C.C., Iweala, E.E.J., Kanu, I. 2009. Effect of processing methods on the nutritive and antinutritive properties of seeds of Brachystegia eurycoma and Detarium microcarpum from Nigeria. Pakistan Journal of Nutrition, 8(4), 316-320.

Ward, J.L., Poutanen, K., Gebruers, K., Piironen, V., Lampi, A.M., Nystrom, L., Andersson, A. A.M., Aman, P., Boros, D., Rakszegie, M., Bedo, Z., Shewry, P.R. 2008. The HEALTHGRAIN cereal diversity screen: concept, results and prospects. Journal of Agriculture and Food Chemistry, 56, 9699-9709.

Yotsawimonwat, S., Sriroth, K., Kaewvichit, S., Piyachomkwan, K., Jane, J.L., Sirithunyalug, J. 2008. Effect of $\mathrm{pH}$ on complex formation between debranched waxy rice starch and fatty acids. International Journal of Biological Macromolecules, 43, 94-99.

Zhu, F., Cai, Y-Z., Sun, M., Corke, H. 2008. Effect of Phenolic Compounds on the Pasting and Textural Properties of Wheat Starch. Starch, 60, 609-616. 